\title{
A Development of Augmented Reality Mobile Application to Promote the Traditional Indonesian Food
}

https://doi.org/10.3991/ijim.v14i09.11179

\author{
Alfian Nara Weking, Suyoto( $\left.{ }^{\varpi}\right)$, Albertus Joko Santoso \\ Universitas Atma Jaya Yogyakarta, Yogyakarta, Indonesia \\ suyotodstaff.uajy.ac.id
}

\begin{abstract}
Traditional food is a representation of the culture and identity of certain regions and is a symbol of cultural heritage. Traditional Indonesian food must be preserved and introduced to the community, especially the easy generation as the next generation of the nation as a form of love for the culture that has been passed down from generation to generation. It aims to avoid the influence of food or foreign cuisine that enters Indonesia, which from time to time makes the preservation of traditional Indonesian food increasingly eroded. One form of an effective cultural approach is by introducing to the easy generation and also to the wider community. Therefore the use of technology is very important to maintain the preservation of traditional Indonesian food and convey it to the community, especially the easy generation. This study aims to develop a mobile application for augmented reality as a promotional medium to introduce traditional Indonesian food. Mobile augmented reality in applications built with the Unity3D program is done in different ways in presenting information to other media. This method allows users to view the media as a presentation of their information in the form of $2 \mathrm{D}$ and or 3D image modelling by using tracking images through a smartphone device's camera. The mobile augmented reality application that will be developed can provide an interesting and interactive information experience so that it can be fun for every user so that knowledge of traditional Indonesian food can be distributed and channeled so that the preservation of traditional Indonesian food is maintained.
\end{abstract}

Keywords - Augmented Reality Mobile Application, Traditional Indonesian Food, Promotion

\section{$1 \quad$ Introduction}

Traditional food represents a sense of pleasure that has become a culture, trustworthiness, identity and is a symbol of the cultural heritage of a particular region [1]. The inheritance of cultural wealth has become one of the potentials in Indonesia, which is a dissection between other countries. Studies show that traditional food has a positive contribution to health because in terms of its composition has a variety of different nutrients [2]. However, some concerns arise among countries regarding the potential loss of food and knowledge of traditional food among the easy generation [3]. Therefore, to introduce traditional Indonesian food to the easy generation and society, various 
efforts have been made mainly to promote traditional Indonesian food through various media such as online media, brochures, advertisements and so on. The results of observations show that promoting traditional Indonesian food through online media, brochures, and advertisements have not been able to meet the needs of users, because the presentation of information is less interesting and less active and tends to watch.

The increasing use of smartphones has changed the behaviour of every person's life, thus encouraging everyone to use mobile applications in very varied situations [4]. Studies have proven that mobile augmented reality is very effective in presenting interesting and interactive information [5] [6] [7] [8] [9]. Mobile augmented reality technology is a new trend in giving users an additional view of digital information in the real world [10]. Augmented reality can combine virtual objects like text, images, and animations into the real world in real time [8]. Augmented reality is also used in the field of education because of the ability that can effectively help users to achieve learning goals [11], that is, it can convey abstract concepts and present 3D context information into real objects [12]. Augmented reality technology can be accessed through smartphone and tablet mobile devices because smartphones have the long-lasting processing power [13] and use the camera to capture images and display objects on the screen [14]. By utilising the augmented reality application embedded on a smartphone, stakeholders can develop their own augmented reality mobile applications based on cultural heritage resources such as historical information to attract visitors and to gain knowledge about their cultural heritage [15] [16] [17]. Thus the information on the cultural heritage mentioned above can be channelled using presenting interesting and interactive information.

Based on the study above, researchers want to develop mobile augmented reality application to promote traditional Indonesian food by utilising augmented reality technology and smartphones. This paper is organised based on the sequence and systematic flow that will be developed. The initial section is an introduction to research, followed by a literature review related to the research topic and a brief explanation of the research methodology.

\section{$2 \quad$ Literature Review and Related Works}

Many studies have proven that the use of augmented reality technology effectively produces something interesting and very interactive.

Seran Bria, Marianus Magno et al. [14] utilise augmented reality on a mobile application to promote Tais Timor Leste fabric. They consider the book about Tais produced by SEAC has not been able to meet user needs because the information is less interesting and interactive. The results of the study show that using applications that have been developed can introduce Tais Timor Leste more interestingly and interactively.

Yulia, Cica et al. [1], an application called AR Ma'Ugiz was developed to introduce traditional Sundanese food for nutrition education for teenagers. The development of augmented reality technology as a medium for the introduction of traditional Sundanese food for teenagers is very interesting and fun for them. Also, more teenagers have the 
opportunity to explore food in terms of the manufacturing process and nutritional information so that they unconsciously apply local wisdom values and love their culture, including their traditional food.

Bostanci, Erkan et al. [18] discuss the use of Kinect sensors for augmented reality applications in introducing cultural heritage. The results of the study show that the use of Kinect and augmented reality can increase the effectiveness of applications in introducing cultural heritage.

Kurniawan, Michael $\mathrm{H}$ et al. [19] have the problem of students experiencing difficulties in understanding human anatomy due to constraints of visualisation from 2D to 3D images, so that they develop augmented reality technology for human body anatomy learning systems. The results of the study show that by developing a visualisation system of the masculine body anatomy that is produced in augmented reality can help and improve student learning with more interactive and easier and more enjoyable.

Abou El-Seoud, Samir dan Taj-Eddin, Islam [13] has used Android Augmented Reality technology for Fashion Shopping Retail. Some obstacles in the process of wearing clothes for the actual view. The results of the study show that Mobile Augmented Reality can be used by the Retail Fashion industry to improve consumer experience in shopping for clothes. Besides, the use of augmented reality can increase brand and trust in consumers.

Westerfield, Giles et al. [12] in their research, they combined Augmented Reality (AR) technology with Intelligent Tutoring Systems (ITS) for learning how to assemble computer motherboards - combining AR graphics with ITS guidelines to provide a more effective learning experience. The evaluation results show that an intelligent AR system can increase the score by $25 \%$ and task performance $30 \%$ faster than the same AR system without being supported by the intelligence.

Pradibta, Hendra [8] develop Augmented Reality as an alternative learning media for early education students at Al Furgon. The learning material used is the Daily Prayer, which was originally still in the form of text. The application developer can combine virtual objects like text, images, and animation. The results show that augmented reality technology can be used as an alternative learning media especially in the learning process because content from augmented reality in the form of animation can provide more understanding and attention for early education students.

Waruwu, Adi Ferliyanto et al. [20] has implemented Augmented Reality technology on a mobile application to provide an information system about tourist attractions in Bali, especially attractions in Tanah Lot Temple. This application called DewataAR can display $3 \mathrm{D}$ objects, videos and audio about the Tanah Lot temple after scanning objects from the tourist brochure using a smartphone camera. The results of the study show that the DewataAR application can be an alternative media for promoting tourist attractions that are attractive to tourists.

Indrawan, I Wayan Andis et al. [21] in his research developing Markerless Augmented Reality using a Gyroscope to demonstrate the position of Nawa Sanga Dewata. They argue that in social life, the concept of the Gods of Nawa Sanga has not been inherent and understood by all Balinese Hindus. So that the augmented reality application with the Gyroscope is designed to know, recognise and understand the characteristics of the Nawa Sanga Gods. This sensor can function to display the objects of the 
gods at predetermined coordinates and also serves to provide information in a more innovative and informative 3D form. Thus, the development and application of augmented reality and smartphone technology are an alternative media that is very interesting and interactive. Also, it can display virtual objects like text, images, videos, and animations in real terms so that the augmented reality technology on smartphones is very effective to develop as a fun visualisation medium for its users.

\section{$3 \quad$ Method and Materials}

The research method is the sequence of steps or stages that are used as workflows in conducting a study [21]. The sequence and steps in this study can be seen in Fig. 1.

In this study, the first step taken was conducting a review and observation of the process of introducing traditional Indonesian food. In this step, we will observe various promotional media and introduce traditional Indonesian food. Along with this, literature studies are conducted by looking for research literature related to research topics, namely reading various library sources from the internet, theses, papers, and books. The next step is to identify the problem with the process of introducing traditional Indonesian food. After the problem is identified, analysis can be done to find a solution. The next step is to propose a solution that is designing and developing applications for introducing traditional Indonesian food. Making an application begins with creating a storyboard. The application focuses on application interaction design, namely conceptual design and physical design. Conceptual design relates to how the application can work and also how it looks attractive and interactive. Physical design is related to the elements in the application, such as images, menus, and icons that are needed in the application for introducing traditional Indonesian food. After the design process is complete, the application functionality will be tested.

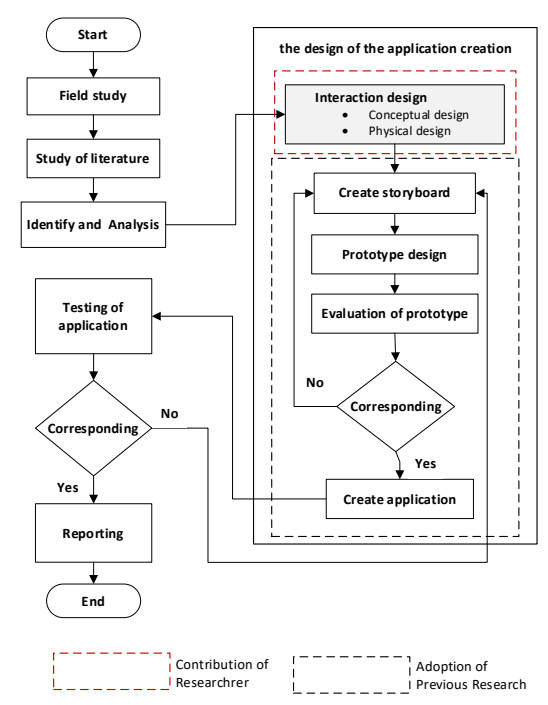

Fig. 1. Research Workflow Diagram 


\subsection{Identification and analysis}

In recent years, mobile augmented reality applications have increasingly been developed and used as media in various fields such as education and learning [22] [23] [24], tourism and culture [25] [26] [17], for promotion and marketing media [7] [14] and also as a media visualization of information about nutrition education [27] [1].

Stakeholders promote traditional Indonesian food as an introduction. They do it through social media, brochures, and advertisements to be able to attract the attention of its users. However, based on the identification that has been done that the media introduction through the media is still less attractive and less interactive because it seems ordinary. They tend to make the media an ordinary spectacle. The content of text and images used as a presentation of traditional Indonesian food information provided in the media is less attractive and interactive so that knowledge of traditional Indonesian food is not distributed and channelled to visitors or users.

The following is an analysis of the solutions resulting from the identification carried out.

- The media developed must be user-friendly

- The content displayed must make it easier for users

- The use of text and images is designed to be more interesting and interactive so that users are free to explore traditional Indonesian food.

\section{$4 \quad$ Results and Discussion}

\subsection{Application architecture}

Users use a smartphone camera to detect the prepared marker. The created marker will be uploaded to the "vuforia" database. Objects and information about traditional Indonesian food will be displayed to users through a smartphone camera. Fig. 2 shows the architecture of the augmented reality of traditional Indonesian mobile application.

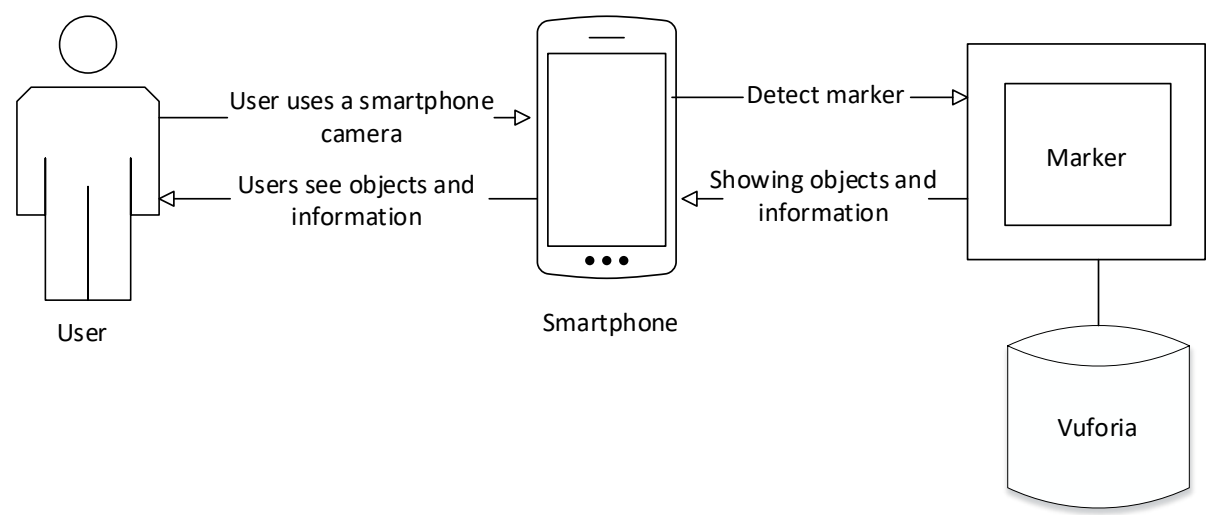

Fig. 2. The architecture of Mobile Augmented Reality Application the Traditional Food 


\subsection{User interface design}

From the goal to be achieved is to develop a mobile application augmented reality introduction of traditional Indonesian food, then designed or designed by considering the conceptual and physical side. From a conceptual side, it is determined what and how the mobile augmented reality introduction of traditional food should work.

In this augmented reality mobile application, one of the considerations is displaying information on traditional Indonesian food that is interesting, interactive and fun for its users. The presentation of information used in this application is by displaying 2D images and or 3D traditional foods of Gudeg, Lotek, and Bose. From the physical side beside the 3D image display of traditional Indonesian food, and there are also icons, menus and text colours and other elements that will be used and displayed in the augmented reality mobile application. The icon specified in this augmented reality application is like a camera icon as a direction to the marker scan - other icons like the icon on the about button and the icon on the instructions button.

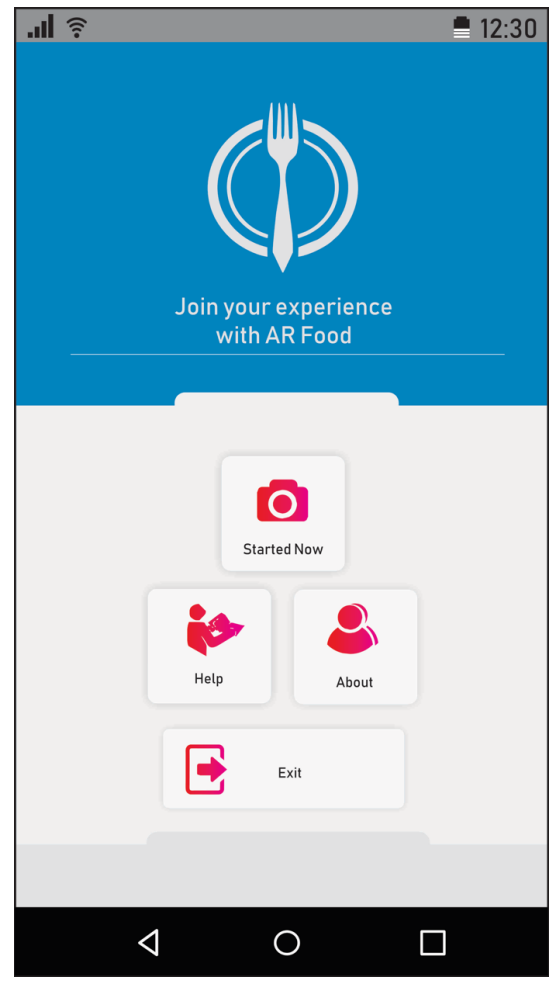

Fig. 3. Home Interface 


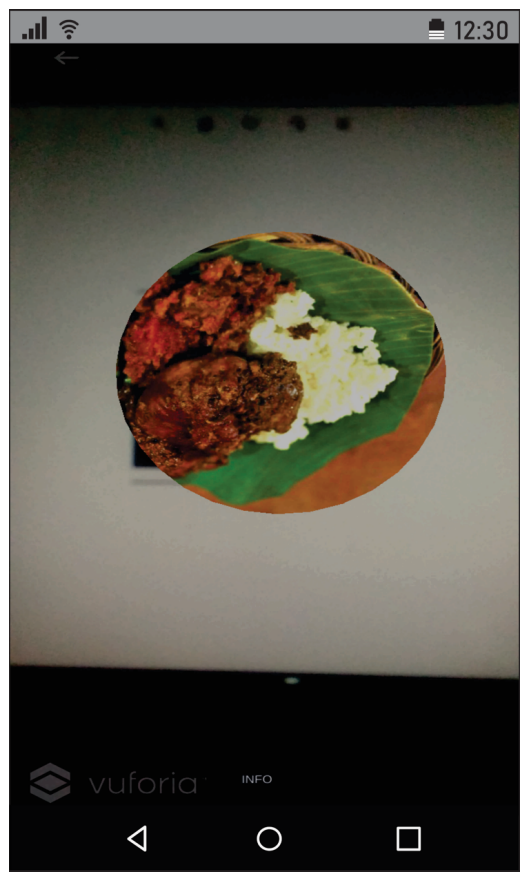

Fig. 4. The interface of image object about traditional food

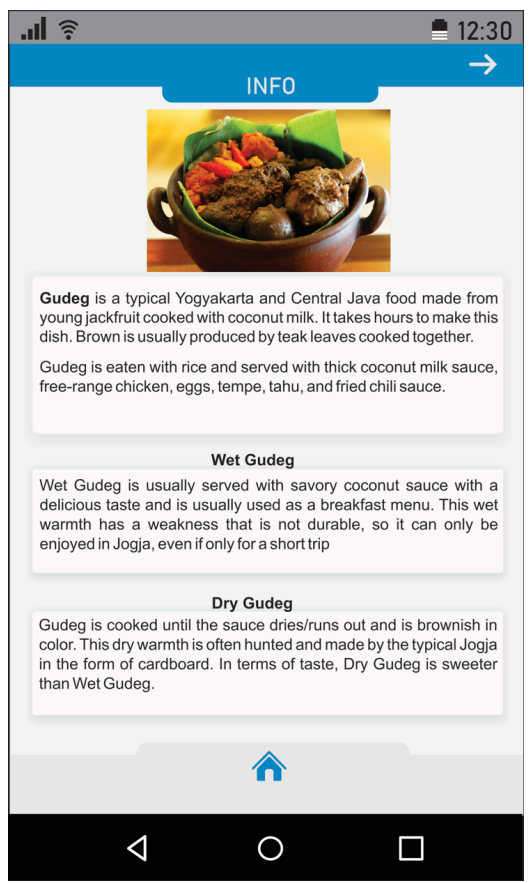

Fig. 5. Information about traditional food 
The mobile augmented reality application has been designed. This application is called AR-Food. Fig. 3 shows the main menu display prototype. This main menu is made of 4 buttons that are designed with a user-friendly icon to make it easier for users to do activities to explore traditional Indonesian food using augmented reality technology that has been installed on the Android smartphone. Fig. 4 is a traditional display view that has been designed in the form of a 3D image. The display is made interesting and interactive so that users can see and follow traditional food information with fun content. Information about traditional Indonesian food is shown in Fig. 5.

\subsection{Testing of application}

The black box testing method is used in testing this application. The black box testing method is a software testing method that tests the functionality of an application. Through the black box testing method, this application will be tested in four aspects.

The first aspect, namely the installation of AR-Food applications on an Android smartphone that has been designed. The second aspect, regarding whether the application can be run on an Android smartphone properly. The third aspect, related to buttons or features in the application, namely, the start button, the help button, the about button, the exit button, and other buttons designed in each scene on the application. The fourth aspect is the detection of markers that have been made. Markers made are then uploaded to the vuforia database, so that they can be detected by the augmented reality that has been designed. "Vuforia SDK" is installed on the Uni-ty3D software. The test results show when the object being detected can be displayed and travelled properly.

If the functionality of the AR-Food application is not maximal or not in line with expectations when testing, it can be fixed again as in the flow of making applications until this application can run perfectly.

\section{Conclusion}

AR-Food application has been designed and tested and can run well. It is proven that this application can attract the attention of users to explore traditional Indonesian food. Traditional Indonesian foods displayed on this application are Gudeg, Lotek, and Bose. This application is very interactive, so it can be fun for its users in promoting and introducing traditional Indonesian food to the community, especially the young generation of Indonesia. The application that was designed and built on Android Smartphone is also very user-friendly because nowadays most people have and use Android gadgets to fulfil their life needs.

\section{References}

[1] C. Yulia, H. Hasbullah, E. E. Nikmawati, S. R. Mubaroq, C. U. Abdullah, and I. Widiaty, "Augmented reality of traditional food for nutrition education," MATEC Web Conf., vol. 197, p. 16001, Sep. 2018. https://doi.org/10.1051/matecconf/201819716001 
[2] Z. Du Plooy, H. C. Schönfeldt, and N. Hall, "The role of traditional foods in food-based dietary guidelines - A South African case study on maas (cultured milk)," Food Chem., vol. 238, pp. 22-28, 2018. https://doi.org/10.1016/j.foodchem.2017.04.044

[3] M. Sharif, M. Zahari, N. Ishak, R. Muhammad, A. Noor, and H. Salleh, "Traditional Food Knowledge (TFK) of Malay festive foods," in Current Issues in Hospitality and Tourism, no. January, CRC Press, 2012, pp. 365-369. https://doi.org/10.1201/b12752-72

[4] J. Novak-Marcincin, M. Janak, J. Barna, and L. Novakova-Marcincinova, New Perspectives in Information Systems and Technologies, Volume 2, vol. 276. Cham: Springer International Publishing, 2014. https://doi.org/10.1063/1.4707641

[5] P. Haynes, S. Hehl-Lange, and E. Lange, "Mobile Augmented Reality for Flood Visualisation," Environ. Model. Softw., vol. 109, no. May, pp. 380-389, 2018. https://doi.org/10. 1016/j.envsoft.2018.05.012

[6] K. L. Tan and C. K. Lim, "Development of traditional musical instruments using augmented reality (AR) through mobile learning," in AIP Conference Proceedings, 2018, vol. 2016, no. September, p. 020140. https://doi.org/10.1063/1.5055542

[7] H. D. Hermawan, A. Saputri, and Hafizhah, "Augmented reality T-shirt for product promotion," in AIP Conference Proceedings, 2018, vol. 1977, no. June, p. 030036. https://doi.org/10.1063/1.5042956

[8] H. Pradibta, “Augmented Reality: Daily Prayers for Preschooler Student," Int. J. Interact. Mob. Technol., vol. 12, no. 1, p. 151, Jan. 2018. https://doi.org/10.3991/ijim. $\underline{\mathrm{v} 12 \mathrm{i} 1.7269}$

[9] N. A. M. El Sayed, H. H. Zayed, and M. I. Sharawy, "ARSC: Augmented reality student card An augmented reality solution for the education field," Comput. Educ., vol. 56, no. 4, pp. 1045-1061, 2010. https://doi.org/10.1016/j.compedu.2010.10.019

[10] H. A. Sulaiman, M. A. Othman, M. F. I. Othman, Y. A. Rahim, and N. C. Pee, Advanced Computer and Communication Engineering Technology, vol. 362. Cham: Springer International Publishing, 2016.

[11] A. F. Abate and M. Nappi, "Guest Editorial: Augmented Reality Based Framework for Multimedia Training and Learning," Multimed. Tools Appl., vol. 75, no. 16, pp. 9507-9509, Aug. 2016. https://doi.org/10.1007/s11042-016-3551-7

[12] G. Westerfield, A. Mitrovic, and M. Billinghurst, "Intelligent augmented reality training for motherboard assembly,” Int. J. Artif. Intell. Educ., vol. 25, no. 1, pp. https://doi.org/10.10 07/s40593-014-0032-x

[13] S. Abou El-Seoud and I. Taj-Eddin, “An Android Augmented Reality Application for Retail Fashion Shopping," Int. J. Interact. Mob. Technol., vol. 13, no. 01, p. 4, 2019.https://doi.org/10.3991/ijim.v13i01.9898

[14] M. M. Seran Bria, G. P. Kusuma, and L. K. Putera Suryapranata, "Promoting Timur Leste's Tais Cloth Using Mobile Augmented Reality Application,” Procedia Comput. Sci., vol. 135, pp. 700-706, 2018. https://doi.org/10.1016/j.procs.2018.08.216

[15] U. C. Pendit, S. B. Zaibon, and J. A. A. Bakar, "Measuring enjoyable informal learning using augmented reality at cultural heritage site," in Journal of Telecommunication, Electronic and Computer Engineering, 2016, vol. 8, no. 10, p. 020087. https://doi.org/10.1063/ 1.4960927

[16] L. W. Shang, T. G. Siang, M. H. Bin Zakaria, and M. H. Emran, "Mobile augmented reality applications for heritage preservation in UNESCO world heritage sites through adopting the UTAUT model," in AIP Conference Proceedings, 2017, vol. 1830, p. 030003.https://doi.org/10.1063/1.4980928

[17] A. Roongrungsi, C. S. Namahoot, and M. Brückner, "Augmented reality application for cultural and historical tourist attraction display (ARCH-TOUR)," J. Telecommun. Electron. Comput. Eng., vol. 9, no. 2-4, pp. 65-69, 2017. 
[18] E. Bostanci, N. Kanwal, and A. F. Clark, “Augmented reality applications for cultural heritage using Kinect," Human-centric Comput. Inf. Sci., vol. 5, no. 1, p. 20, Dec. 2015. https://doi.org/10.1186/s13673-015-0040-3

[19] M. H. Kurniawan, Suharjito, Diana, and G. Witjaksono, "Human Anatomy Learning Systems Using Augmented Reality on Mobile Application," Procedia Comput. Sci., vol. 135, pp. 80-88, 2018. https://doi.org/10.1016/j.procs.2018.08.152

[20] A. F. Waruwu, I. P. Agung Bayupati, and I. K. Gede Darma Putra, "Augmented Reality Mobile Application of Balinese Hindu Temples: DewataAR," Int. J. Comput. Netw. Inf. Secur., vol. 7, no. 2, pp. 59-66, Jan. 2015. https://doi.org/10.5815/ijenis.2015.02.07

[21] I. W. A. Indrawan, I. P. A. Bayupati, and D. P. Singgih Putri, "Markerless Augmented Reality Utilizing Gyroscope to Demonstrate the Position of Dewata Nawa Sanga," Int. J. Interact. Mob. Technol., vol. 12, no. 1, p. 19, Jan. 2018. https://doi.org/10.3991/ijim.v12i1.7527

[22] E. Miranda Bojórquez, O. O. Vergara Villegas, V. G. Cruz Sánchez, J. L. García-Alcaraz, and J. Favela Vara, "Study on Mobile Augmented Reality Adoption for Mayo Language Learning,” Mob. Inf. Syst., vol. 2016, pp. 1-15, 2016. https://doi.org/10.1155/2016/1069581

[23] S. S. Jamali, M. F. Shiratuddin, K. W. Wong, and C. L. Oskam, "Utilising Mobile-Augmented Reality for Learning Human Anatomy," Procedia - Soc. Behav. Sci., vol. 197, no. February, pp. 659-668, 2015. https://doi.org/10.1016/j.sbspro.2015.07.054

[24] N. A. Abd Majid and N. Abd Majid, "Augmented Reality to Promote Guided Discovery Learning for STEM Learning,” Int. J. Adv. Sci. Eng. Inf. Technol., vol. 8, no. 4-2, p. 1494, Sep. 2018. https://doi.org/10.18517/ijaseit.8.4-2.6801

[25] A.-C. Haugstvedt and J. Krogstie, "Mobile augmented reality for cultural heritage: A technology acceptance study," in 2012 IEEE International Symposium on Mixed and Augmented Reality (ISMAR), 2012, pp. 247-255. https://doi.org/10.1109/ismar.2012.6402563

[26] S. A. I. A. Shukri, H. Arshad, and R. Z. Abidin, "The design guidelines of mobile augmented reality for tourism in Malaysia," in AIP Conference Proceedings, 2017, vol. 1891, no. October, p. 020026. https://doi.org/10.1063/1.5005359

[27] M. Z. Bayu, H. Arshad, and N. M. Ali, "Nutritional Information Visualization Using Mobile Augmented Reality Technology," in Procedia Technology, 2013, vol. 11, no. Iceei, pp. 396402. https://doi.org/10.1016/j.protcy.2013.12.208

\section{$7 \quad$ Authors}

Alfian Nara Weking is a Master of Informatics Engineering at the Atma Jaya University in Yogyakarta, Yogyakarta, Indonesia. A graduate from STMIK Denpasar, Bali, Indonesia. Interest in mobile applications, multimedia, web programming, and UI / UX design.

Suyoto is a professor from the Department of Informatics at Atma Jaya University in Yogyakarta, Yogyakarta, Indonesia. Has more than 18 years of teaching experience. Received a Ph.D. in 2000 from the National University of Malaysia, Malaysia. His research interests are multimedia, computer graphics, visualization, mobile applications, and artificial intelligence. Email: suyoto@staff.uajy.ac.id

Albertus Joko Santoso is currently a senior lecturer in the Department of Informatics at Atma Jaya University in Yogyakarta, Yogyakarta, Indonesia. Received a Ph.D. at Gadjah Mada University in 2012. Research interests in image processing, pattern recognition and intelligent systems.

Article submitted 2019-07-03. Resubmitted 2019-11-19. Final acceptance 2019-11-24. Final version published as submitted by the authors. 